\title{
ANALISIS RASIO KEUANGAN DALAM MEMPREDIKSI PERUBAHAN LABA DI MASA YANG AKAN DATANG PADA PT.BANK RAKYAT INDONESIA Tbk (Persero)
}

\author{
Cyndia Pangerapan ${ }^{1}$, David Saerang ${ }^{2}$, Hence Wokas ${ }^{3}$ \\ ${ }^{1,2,3}$ Jurusan Akuntansi, Fakultas Ekonomi dan Bisnis,Universitas Sam Ratulangi, Jl.Kampus Bahu, Manado, \\ 95115, Indonesia \\ Email : cyndiapangerapan@yahoo.com
}

\begin{abstract}
In predicting the financial condition of banks it need relevant, accurate and reliable financial information and useful for internal and external parties the bank itself and presented in the financial statements. This research was conducted at PT. Bank Rakyat Indonesia (Persero) Tbk which is enganged in the banking business. The research obective was to analze the predictive ability of financial ratios in the case ROE, PER and Turnover Total Assets to change in earnings in the future. Data analysis method uses is multiple linear regression analysis with the help of SPSS Software.
\end{abstract}

Keywords: ROE, PER, turnover total assets.

\section{PENDAHULUAN}

Munculnya fenomena globalisasi keuangan secara menyeluruh baik di negara maju maupun negara sedang berkembang yang nam pak dalam bentuk liberalisasi pasar modal, arus pergerakan modal secara bebas yang tidak dibatasioleh batas wilayah suatu negara yang dipengaruhi oleh kemauan teknologi informasi yang telah menghasilkan inovasi-inovasi baru yang telah terwujud dalam bentuk produk-produk layanan bank. Kondisi tersebut berkontribusi menciptakan tingkat persaingan secara global yang ketat dan sulit diprediksi sebagai tantangan, akan tetapi kondisi itu juga telah membuka peluang untuk meraih keuntungan-keuntungan yang besar dengan resiko-resiko yang baru pula.

Usaha industri perbankan memegang peranan penting dalam mendorong pertumbuhan perekonomian suatu negara. Sejalan dengan perkembangan ekonomi maka peran bank sebagai tiang penyangga yang mendorong peningkatan ekonomi nampak dalam jangkauan usahanya yang semakin luas dan merambat keseluruh lapisan masyarakat sebagai mitra usaha yang mensuplai dan mengakomodir dana dari masyarakat secara menyeluruh. Dalam kegiatan usahanya yang menghimpun dana dari masyarakat dalam bentuk tabungan,deposito dan menyalurkan kredit dan jasa-jasa dalam lalu lintas pembayaran serta peredaran uang, telah mengalami perkembangan yang pesat, diiringi pula dengan peningkatan kualitas manajemen dan mutu layanan yang maksimal untuk memelihara dan meningkatkan kepercayaan masyarakat sebagai pengguna jasa yang sempat mengalami kemerosotan pada satu dasawarsa lalu.

Tujuan analisis rasio adalah memperoleh informasi kemampuan perusahaan baik dalam memenuhi kewajibanya maupun untuk memperoleh laba dan mempertahankan stabilitas usahanya. Dengan adanya rasio ini kita dapat menganalisis pos keuangan dengan baik karena :

1 Rasio merupakan angka atau ikhtisar statistik yang lebih mudah dibaca dan ditafsirkan.

2 Rasio merupakan pengganti yang lebih sederhana dari informasi yang diajikan laporan keuangan yang sangat rinci dan rumit. 
3 Mengetahui posisi perushaan ditengah industri lain.

4 Sangat bermanfaat untuk bahan dalam mengisi model pengambilan keputusan dan model prediksi.

5 Menstandari size perusahaan.

6 Lebih mudah memperbandingkan peruahaan dengan perusahaan lain atau melihat perkembangan perusahaan secara periodik atau 'timeseries'

7 Lebih mudah melihat trand perusahaan serta melakukan prediksi dimasa yang akan datang.

Disamping keunggulan yang dimiliki analisis rasio, teknik ini juga memiliki keterbatasan yang harus disadari sewaktu penggunaanya agar kita tidak salah dalam penggunaanya.

\section{Tujuan Penelitian}

1. Bagi Perbankan

Hasil peneliatian ini diharapkan dapat bermanfaat bagi pihak perbankan sebagai masukan dan bahan pertimbangan dalam pengambilan keputusan ekonomi. Selain itu dapat memberikan kontribusi praktis untuk PT.Bank Rakyat Indonesia (Persero), Tbk dalam memprediksi laba dimasa yang akan datang.

2. Bagi Pembaca

Penelitian ini diharapkan apat bermanfaat bagi pembaca sebagai bahan kontribusi dalam melakukan penelitian selanjuutnya mengeanai analisi rasio keuangan dalam memprediksi perubahan laba.

3. Bagi Penulis

Penelitian ini dapat bermanfat bagi penulis untuk meningkatkan pengetahuan alam menganalisis rasio keuangan suatu perusahaan dalam hal meneliti, menguji dan atau mengobsevasi fenomena dan permasalahan yang terjadi.

\section{TINJAUAN PUSTAKA}

Penelitian mengenai pengaruh kinerja keuangan juga pernah diteliti oleh Heru, Tjaraka (2005) dari Fakultas Ekonomi Universitas Airlangga di Surabaya yang berjudul "Analisis Variabel-Variabel Fundamental yang Berpengaruh Terhadap Harga Saham LQ 45 Di Bursa Efek Jakarta". Penelitian tersebut bertujuan untuk mengetahui seberapa besar pengaruh beberapa variabel fundamental terhadap saham LQ 45 di Bursa Efek Jakarta dan mengetahui variabel fundamental yang berpengaruh paling besar terhadap harga saham LQ45 di Bursa Efek Jakarta. Dari kajian teoritik ditentukan empat variabel fundamental yang diduga mempengaruhi harga saham LQ45, yaitu: Earnings per share, Return on Equity, Debt Equity Ratio dan Current Ratio. Data dalam penelitian ini merupakan data ratio sehingga bisa diuji dengan statistik parametrik yaitu multiple regression. Sampel penelitian ini adalah perusahaan-perusahaan LQ 45,yaitu perusahaan yang sahamnya aktif diperjualbelikan di bursa. Penarikan sampel rnenggunakan simple random sampling. Uji hipotesis menggunakan model multiple regression dengan harga saham sebagai variabel terikat dan EPS,ROE, DER dan CR sebagai variabel bebas. Hasil pengujian dapat disimpulkan bahwa seeara bersamasama terdapat pengaruh yang signifikan (nyata) antar variabel EPS(X1), ROE(X2), DER (X3) dan CR(X4) terhadap harga saham (Y). Dengan koefisien determinasi (R2) sebesar 0,745 menunjukkan proporsi pengaruh variabel bebas $(\mathrm{X})$ seeara bersama-sama terhadap variabel terikat (Y), artinya secara signifikan dengan tingkat kepercayaan $95 \%$ sebesar 74,5\% mampu menjelaskan perubahan variabel terikat yaitu harga saham (Y) disebabkan oleh perubahan secara bersama-sama variabel EPS (X1), ROE(X2), DFR(X3), dan CR(X4), sedangkan sisanya sebesar $25,5 \%$ dipengaruhi oleh variabel lain yang tidak termasuk dalam penelitian ini. Sedangkan dari uji t menunjukkan variabel earning per share merupakan variabel yang paling dominan terhadap harga saham LQ 45. 


\section{Pengertian Analisis Rasio Keuangan}

Analisis rasio adalah suatu alat analisis yang mengubungkan atau memperbandingkan suatu jumlah tertentu dengan jumlah yang lain, serta mengidentifikasi hubungan antara keduanya. Misalnya dengan menghubungkan jumlah pada suatu pos tertentu dengan jumlah pada pos lain dalam neraca, akan diperoleh perbandingan (ratio) yang dapat menggambarkan baik atau buruknya posisi keuangan perusahaan yang bersangkutan. Tujuan analisis rasio adalah memperoleh informasi kemampuan perusahaan baik dalam memenuhi kewajibanya maupun untuk memperoleh laba dan mempertahankan stabilitas usahanya.

\section{Laba di masa yang akan datang}

Pada dasarnya laba ditungkan dalam 2 konsep yaitu laba menurut konsep dan laba menurut konsep ekoomi. Paraekonom mendefinisikan laba dari sudut pandang orang, kelompok orang atau masyarakat, secara keseluruhan sebagai pusat penelitian. Laba dalam praktek pembukuan terdapat kebiasaan yang mendefinisikannya sebagai bertambahnya kekayaan sendiri dalam periode, selama laba itu ditetapkan. Bertambahnya kekayaan dihitung dengan jumlah mengurangi besarnya kekayaan sendiri menurut neraca pada akhir periode. Dengan demikian, maka penetapan laba dilakukan dengan perbandingan dari dua neraca yang berturut-turut.

\section{Laba Sebagai alat Ramal}

Salah satu konsep perilaku laba menurut Sofyan (2011:45) adalah kemampuan ramal. Laba operasi selama bebeapa periode berguna untuk meramalkan operasi perusahaan yang akan datang jika factor relavan lainnya kut dipertimbangkan. Pemilik bisnis mungkin tertarik dalam meramalkan atau pedapatan neto di masa yang akan datang. Pemilik perusahaan, kreditur dan pihak lainya ingin menilai prospek arus masuk kas bersih perusahaan, tetapi mereka sering, menggunakan laba untuk membantu mereka mengevaluasi daya laba (earning power), mereka meramal laba yang akan datang atau menaksir risiko berinvestasi. Jadi diasumsikan ada hubugan antara laba yang dilaporkan dengan arus kas, termasuk distribusi kas kepada melikik. Oleh karena itu pengharpan akan laba yang akan datang digunakan oleh pemilik bisnis sebagai factor utama dalam meramalkan distribusi pendapatan netto di masa yang akan datang. Pengguanan angka laba membantu manajemen dalam meramalkan keadaan laba dimasa yang akan mendatang.

\section{Rasio Keuangan dalam Memprediksi Perubahan Laba di Masa Yang Akan Datang}

Untuk mengambil manfaat dari rasio keuangan kita memerrlukan standar untuk perbandingan. Salah satu pendekatan adalah membandigkan rasio perusahaan dengan pola untuk industry atau lini usaha dimana perusahaan secara dominan beroperasi. Pendekatan ini didasarkan pada premis bahwa beberapa kekuatan ekonomi dan bisnis yang mendasar memaksa seluruh perusahaan dalam suatu industri untuk berprilaku serupa. Pendekatan lain adalah lembar kerja bank investasi, meliputi penyusunan data untuk satu perusahaan berdampingan dengan data untuk sejumlah perusahaan terpilih lain yang sebanding. Dengan menganalisa kelompok perusahaan yang sebanding dapat memberikan pengertian tentang factor strategis dan ekonomis yang lebih luas yang mempengaruhi kelompoktersebut (Mabue Kumbirai dan Robert Webb, 2010).

\section{Prinsip Dasar Pengendalian Internal}

a. Ada beberapa asumsi dasar yang perlu dipahami mengenai pengendalian internal bagi suatu entitas organisasi atau perusahaan.

b. Menurut Sanyoto (2007 : 256) Sistem pengendalian internal merupakan management responsibility. Bahwa sesungguhnya yang paling berkepentingan terhadap sistem pengendalian internal suatu entitas organisasi/ perusahaan adalah manajemen (lebih tegasnya lagi ialah top management / direksi), karena dengan sistem pengendalian internal yang baik itulah top management dapat 
mengharapkan kebijakan dipatuhinya, aktiva atau harta perusahaan dilindungi, dan penyelenggaraan pencatatan berjalan baik.

c. Hasil perhitungan kas direkam dalam berita acara penghitungan kas dan disetor penuh ke bank dengan segera

d. Para penagih dan kasir harus diasuransikan (fidelity bond insurance)

e. Kas dalam perjalanan (baik yang ada ditangan bagian kasir maupun di tangan penagih perusahaan) harus diasuransikan (Cash-in-safe dan cash-in-transit Insurance)

\section{METODE PENELITIAN}

\section{Jenis Penelitian}

Dalam penelitian ini tentunya diperlukan data yang berhubungan dengan permasalahan yang dihadapi. Menurut Sugiyono (2010:13), "data adalah sekumpulan informasi yang diperlukan untuk pengambilan keputusan". Data merupakan keteranganketerangan yang diperoleh dari suatu penelitian dan atau melalui referensi untuk dapat digunakan dalam menganalisa permasalahan yang dihadapi dan selanjutnya untuk mencari alternatif yang sesuai.

\section{Tempat Penelitian}

Lokasi penelitian bertempat di Bank Rakyat Indonesia (persero) Tbk jln. Sarapung No.4-6, Wenang Manado.

\section{Metode Pengumpulan Data}

Untuk memperoleh data yang berhubungan dengan penelitian ini, maka teknik pengumpulan data yaitu:

a. Kepustakaan, teknik ini dilakukan dengan cara mendapatkan informasi dari teoriteori dengan cara mempelajari serta mencatat dari buku literature, internet, jurnal, serta bahan informasi lainnya yang berhubungan dengan masalah yang diteliti.

b. Pengambilan data, diperoleh dari Bursa Efek Indonesia serta melalui internet dengan situs www.idx.co.id dan www.bri.co.id untuk melengkapi penyusunan skripsi.

\section{Metode Analisis}

Penelitian ini mengguanakan metode regresi berganda (multiple regression) untuk analisis pengaruh dari variable independent terhadap variable dependent. Model ini dipilih karena penelitian ini dirancang untuk menentukan variable independent yang mempunyai pengaruh terhadapa variable dependen. Model yang dimaksud adalah sebagai berikut:

$$
\mathrm{Yt}+1=\alpha+\beta 1 \mathrm{X} 1 \mathrm{t}+\beta 2 \mathrm{X} 2 \mathrm{t}+\beta 3 \mathrm{X} 3 \mathrm{t}+€
$$

\section{HASIL PENELITIAN DAN PEMBAHASAN}

Analisis Rasio Keuangan PT. Bank Rakyat Indonesia (Persero) Tbk Tabel Perhitungan Tingkat Rasio Keuangan

\begin{tabular}{|c|l|c|c|c|c|c|}
\hline \multirow{2}{*}{ No } & \multicolumn{2}{|c|}{ Rasio Keuangan } & \multicolumn{5}{|c|}{ Jumlah (\%) } \\
\cline { 3 - 7 } & & 2010 & 2011 & 2012 & 2013 & 2014 \\
\hline 1 & ROE & 43,83 & 42,49 & 38,66 & 34,11 & 31,22 \\
\hline 2 & PER & 10,95 & 10,73 & 8,92 & 8,83 & 11,86 \\
\hline 3 & Perputaran Total Aktiva & 12,41 & 11,48 & 10,52 & 10,83 & 10,53 \\
\hline
\end{tabular}

a) ROE merupakan salah satu rasio yang menunjukkan kemampuan bank untuk menghasilkan laba atas ekutas atau modal sendiri yang dimiliki. Semakin tinggi nilai ROE berarti kemampuan bank menghasilkan laba atas modal sendiri semakin tinggi, demikian juga sebaliknya. 
Rasio ROE pada PT. Bank Rakyat Indonesia (Persero) Tbk mengalami penurunan dari tahun ke tahun, mulai dari tahun 2010 yaitu 43,83\% sampai tahun 2014 menjadi $31,22 \%$. Penurunan ini disebabkan karena menurunnya tingkat kemampuan bank dalam memperoleh laba atas modal sendiri.

b) Price Earning Ratio (PER) adalah salah satu ukuran paling dasar dalam analisis saham secara fundamental. PER merupakan perbandingan antara harga saham dengan laba bersih bank, dimana harga saham sebuah emiten dibandingkan dengan laba bersih yang dihasilkan oleh emiten tersebut dalam setahun untuk mengetahui wajar atau tidaknya sebuah saham.

Rasio PER PT. Bank Rakyat Indonesia (Persero) Tbk, mengalami penurunan dari tahun 2010 yaitu sebesar 10,95\% sampai tahun 2013 yaitu sebesar 8,83\%, kemudian meningkat di tahun 2014 yaitu sebesar 11,86\%. Hal ini menunjukkan bahwa tingkat kemampuan bank dan efisiensi kinerja bank dalam memperoleh laba dari tahun 2010 sampai tahun 2013 adalah baik namun mengalami penurunan pada tahun 2014.

c) Asset Turnover Ratio atau Perputaran Total Aktiva (PTA) merupakan rasio yang mengkur tingkat efisiensi dan efektivitas dari perputaran maupun pemamfaatan total aktiva dalam menghasilkan laba. Rasio ini menunjukkan banyaknya pendapatan yang dapat diperoleh bank untuk tiap rupiah yang ditanamkan pada aktiva bank. Semakin tinggi rasio ini semakin baik bagi bank.

Rasio Perputaran Total Aktiva pada PT. Bank Rakyat Indonesia (Persero) Tbk mengalami penurunan dari tahun ke tahun. Hal ini menunjukkan bahwa terjadi penurunan pada tingkat kemampuan bank dalam menghasilkan laba.

\section{Analisis Perkembangan Laba PT. Bank Rakyat Indonesia (Persero) Tbk}

Tabel Perubahan Laba PT. Bank Rakyat Indonesia (Persero) Tbk

\begin{tabular}{|c|r|r|c|}
\hline Tahun & Laba (Rp) & Perubahan Laba (Rp) & Prosentase (\%) \\
\hline 2009 & 9.891 .228 & 0 & 0 \\
\hline 2010 & 14.908 .230 & 5.017 .002 & 50,72 \\
\hline 2011 & 18.755 .880 & 3.847 .650 & 25,81 \\
\hline 2012 & 23.859 .572 & 5.103 .692 & 27,21 \\
\hline 2013 & 27.910 .066 & 4.050 .494 & 16,98 \\
\hline 2014 & 30.859 .073 & 2.949 .007 & 10,57 \\
\hline
\end{tabular}

Sumber: PT. Bank Ralyat Indonesia (Persero) Tbk.

Berdasarkan tabel 4.2 dapat dilihat bahwa laba PT. Bank Rakyat Indonesia (Persero) Tbk, mengalami peningkatan dari tahun ke tahun. Pada tahun 2010 PT. Bank Rakyat Indonesia (Persero) Tbk memperoleh laba sebesar Rp. 5.017.002.000.000; dan pada tahun 2014 sebesar Rp. 2.949.007.000.000. Seperti yang kita ketahui, semakin banyak nasabah dan investor yang menanamkan modalnya maka semakin besar laba yang akan diperoleh dari biaya bunga dan biaya lainnya. Sebaliknya jika nasabah dan investor berkurang maka akan menurunkan tingkat laba pada setiap bank.

\section{Analisis Data}

\section{Statistik Deskriptif}

Statistik deskriptif variabel-variabel penelitian ini di tampilkan untuk mempermudah dalam mengetahui rata-rata hitung dan standar deviasi dari masingmasing variabel yang diteliti dalam penelitian ini yaitu ROE, PER, Perputaran Total Aktiva dan Perubahan Laba. 
Tabel Statistik Deskriptif Variabel Penelitian

\begin{tabular}{crrrrr}
\hline & N & Minimum & Maximum & Mean & $\begin{array}{c}\text { Std. } \\
\text { Deviation }\end{array}$ \\
\hline ROE (\%) & 5 & 31,22 & 43,83 & 38,06 & 5,37 \\
PER & 5 & 8,38 & 11,86 & 10,16 & 1,46 \\
PTA & 5 & 10,52 & 12,41 & 11,15 & 0,80 \\
PERUBAHAN & & & & & \\
LABA & 5 & 10,57 & 50,72 & 26,25 & 15,26 \\
Valid N (listwise) & 5 & & & & \\
\hline
\end{tabular}

Sumber: Data Olahan Aplikasi SPSS 21.0

Dari tabel dapat dijelaskan bahwa:

1. Rata-rata hitung dan standar deviasi dari variabel X1 (ROE).

Untuk variabel bebas X1 (ROE) diperoleh nilai rata-rata hitung sebesar 38,06 dan nilai standar deviasi sebesar 5,37.

2. Rata-rata hitung dan standar deviasi dari variabel X2 (PER).

Untuk variabel bebas X1 (PER) diperoleh nilai rata-rata hitung sebesar 10,16 dan nilai standar deviasi sebesar 1,46.

3. Rata-rata hitung dan standar deviasi dari variabel X3 (PTA).

Untuk variabel bebas X1 (PTA) diperoleh nilai rata-rata hitung sebesar 11,15 dan nilai standar deviasi sebesar 0,80 .

4. Rata-rata hitung dan standar deviasi dari variabel Y (Perubahan Laba).

Untuk variabel bebas Y (Perubahan Laba) diperoleh nilai rata-rata hitung sebesar 26,25 dan nilai standar deviasi sebesar 15,26.

\section{Uji Asumsi Klasik}

\section{Uji Normalitas}

\section{Tabel 4.4 Hasil Uji Normalitas}

\begin{tabular}{ccr}
\hline & & $\begin{array}{r}\text { Unstandardiz } \\
\text { ed Residual }\end{array}$ \\
\hline N & Mean & 5 \\
Normal Parameters ${ }^{\text {a,b }}$ & Std. & 5,9000000 \\
& Deviation & \\
Most Extreme & Absolute &, 191 \\
Differences & Positive &, 162 \\
Kolmogorov-Smirnov Z &,- 191 \\
Asymp. Sig. (2-tailed) &, 428 \\
\hline
\end{tabular}

Sumber: Data Olahan Aplikasi SPSS 21.0

Hasil pengolahan menggunakan uji Kolmogorov-Smirnov seperti terlihat pada tabel diatas menunjukkan nilai signifikansi sebesar 0,993. Karena nilai signifikansi uji Kolmogorov Smirnov lebih besar dari 0,05 maka dapat disimpulkan bahwa data berdistribusi normal. 


\section{Uji Multikolinearitas}

Tabel 4.5 Hasil Uji Multikolinearitas

\begin{tabular}{|c|c|c|c|c|c|}
\hline & \multirow[t]{2}{*}{ Model } & \multirow[t]{2}{*}{$\mathrm{t}$} & \multirow[t]{2}{*}{ Sig. } & \multicolumn{2}{|c|}{$\begin{array}{c}\text { Collinearity } \\
\text { Statistics }\end{array}$} \\
\hline & & & & Tolerance & VIF \\
\hline \multirow{4}{*}{1} & (Constant) & $-1,407$ & ,393 & & \\
\hline & ROE $(\%)$ & ,565 & ,672 & ,313 & 3,194 \\
\hline & PER &,- 281 & ,826 & ,791 & 1,264 \\
\hline & PTA & ,815 & ,565 & ,283 & 3,535 \\
\hline
\end{tabular}

Berdasarkan tabel diatas, diketahui bahwa nilai Toleransi semua variabel bebas lebih besar dari 0,10 dan nilai VIF semua variabel bebas lebih kecil dari 10,0. Maka dapat disimpulkan bahwa tidak terjadi multikolinearitas pada variabelvariabel bebas tersebut.

3. Uji Heteroskedastisitas

Tabel 4.6 Hasil Uji Heteroskedastisitas

\begin{tabular}{|c|c|c|c|c|}
\hline \multicolumn{2}{|c|}{ Model } & Standardized & $\mathrm{t}$ & Sig. \\
\hline & & Beta & & \\
\hline \multirow{4}{*}{1} & (Constant) & & ,432 & ,740 \\
\hline & ROE $(\%)$ & 1,405 & 2,155 & 277 \\
\hline & PER &,- 043 &,- 104 & ,934 \\
\hline & PTA &,- 743 & $-1,083$ & ,475 \\
\hline
\end{tabular}

Berdasarkan tabel diatas, diketahui bahwa nilai signifikansi semua variabel bebas lebih besar dari 0,05, sehingga dapat disimpulkan bahwa data tidak terjadi masalah heteroskedastisitas pada variabel-variabel bebas.

Analisis Regresi Linear Berganda

Tabel Hasil Uji Regresi Linear Berganda

\begin{tabular}{rcrrrrr}
\hline \multirow{2}{*}{ Model } & \multicolumn{2}{c}{$\begin{array}{l}\text { Unstandardized } \\
\text { Coefficients }\end{array}$} & \multicolumn{2}{c}{$\begin{array}{l}\text { Standardized } \\
\text { Coefficients } \\
\text { Beta }\end{array}$} & t & Sig. \\
& \multicolumn{1}{c}{ B } & Std. Error & Beta & \\
\hline \multirow{4}{*}{1} & (Constant) & 6,536 & 15,114 & & 0,432 & 0,740 \\
& ROE (\%) & 0,698 & 0,324 & 1,405 & 2,155 & 0,277 \\
& PER & $-0,078$ & 0,750 & $-0,043$ & $-0,104$ & 0,934 \\
& PTA & $-2,473$ & 2,283 & $-0,743$ & $-1,083$ & 0,475 \\
\hline
\end{tabular}

Sumber: Data Olahan Aplikasi SPSS 21.0

Berdasarkan tabel di atas, maka dapat diketahui persamaan regresi untuk ROE, PER, dan Perputaran Total Aktiva terhadap Perubahan Laba adalah sebagai berikut:

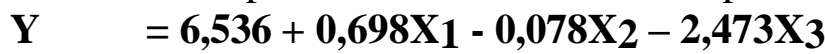

Dimana:

Y $\quad=$ Perubahan Laba

ó $=$ Konstanta

$\mathrm{X}_{1} \quad=$ Return On Equity $(\mathrm{ROE})$

$\mathrm{X}_{2}=$ Price Earning Ratio (PER) 
$\mathrm{X} 3=$ Perputaran Total Aktiva (PTA)

Pada model regresi ini, nilai konstanta sebesar 6,536 yang berarti jika variabel independen pada penelitian ini (ROE, PER, PTA) konstan atau sama dengan nol (0), maka variabel independen diluar model tetap akan berpengaruh terhadap perubahan laba sebesar 6,536 satuan.

Variabel return on equity (ROE) (X1) berpengaruh terhadap perubahan laba (Y) dengan nilai besaran koefisien regresi $\beta 1$ sebesar 0,698 hal ini menunjukkan bahwa setiap satuan variabel ROE akan berpengaruh terhadap perubahan laba sebesar 0,698 apabila variabel lainnya tetap. Dengan kata lain, setiap peningkatan ROE akan berpengaruh dalam memprediksi perubahan laba di masa yang akan datang.

Variabel price earning ratio (PER) (X2) tidak berpengaruh terhadap perubahan laba (Y) dengan nilai besaran koefisien regresi $\beta 2$ sebesar $-0,078$ hal ini menunjukkan bahwa semakin rendah tingkat prosentase rasio PER sebesar 1 skor maka akan cenderung mengalami penurunan laba sebesar -0,0783 satuan dengan asumsi variabel lainnya tetap atau konstan. Dengan kata lain PER tidak berpengaruh dalam memprediksi perubahan laba di masa yang akan datang.

Variabel perputaran total aktiva (PTA) (X3) tidak berpengaruh terhadap perubahan laba (Y) dengan nilai besaran koefisien regresi $\beta 3$ sebesar $-2,743$ hal ini menunjukkan bahwa semakin rendah tingkat prosentase rasio PTA sebesar 1 skor maka akan cenderung mengalami penurunan laba sebesar $-2,743$ satuan dengan asumsi variabel lainnya tetap atau konstan. Dengan kata lain PTA tidak berpengaruh dalam memprediksi perubahan laba di masa yang akan datang.

\section{Uji Parsial (Uji T)}

Uji T digunakan untuk melihat signifikansi dari pengaruh independen secara individu terhadap variabel dependen dengan membandingkan antara $t$ hitung dengan $t$ tabel pada signifikansi 0,05 . Berdasarkan tabel t pada lampiran dengan tingkat signifikansi $0,05 / 2=$ 0,025 dan derajat kebebasan $\mathrm{df}=\mathrm{n}-\mathrm{k}-1$ atau $5-3-1=1$ ( $\mathrm{n}$ adalah jumlah sampel dan $\mathrm{k}$ adalah jumlah variabel independen), maka diperoleh t tabel $=12,71$. Hasil uji t penelitian ini adalah sebagai berikut :

1. Untuk variabel $\mathrm{X} 1$ (ROE), hasil $\mathrm{t}$ hitung $=2,155$ dan $\mathrm{t}$ tabel $=12,71$ dengan nilai signifikansi $=0,277$. Jajdi dapat dilihat bahwa t hitung $<\mathrm{t}$ tabel dan nilai signifikasi $>0,05$. Dengan demikian hasil uji t menyatakan bahwa $\mathrm{H}_{0}$ diterima dan $\mathrm{H}_{1}$ ditolak yang artinya variabel X1 (ROE) tidak berpengaruh dalam memprediksi perubahan laba dimasa yang akan datang.

2. Untuk variabel $\mathrm{X} 2$ (PER), hasil $\mathrm{t}$ hitung $=-0,104$ dan $\mathrm{t}$ tabel $=12,71$ dengan nilai signifikansi $=0,934$. Jadi dapat dilihat bahwa $t$ hitung $<\mathrm{t}$ tabel dan nilai signifikasi $>0,05$. Dengan demikian hasil uji t menyatakan bahwa $\mathrm{H}_{0}$ diterima dan $\mathrm{H}_{2}$ ditolak yang artinya variabel X2 (PER) tidak berpengaruh dalam memprediksi perubahan laba dimasa yang akan datang.

3. Untuk variabel X3 (PTA), hasil t hitung $=-1,083$ dan $\mathrm{t}$ tabel $=12,71$ dengan nilai signifikansi $=0,475$. Jajdi dapat dilihat bahwa t hitung $<\mathrm{t}$ tabel dan nilai signifikasi $>0,05$. Dengan demikian hasil uji t menyatakan bahwa $\mathrm{H}_{0}$ diterima dan $\mathrm{H}_{3}$ ditolak yang artinya variabel X3 (PTA) tidak berpengaruh dalam memprediksi perubahan laba dimasa yang akan datang. 


\section{Uji Simultan (Uji F)}

Uji $\mathrm{F}$ dilakukan untuk menganalisis apakah semua variabel independen yang dimasukkan dalam model mempunyai pengaruh secara bersama-sama terhadap variabel dependen. Dengan demikian uji F diperlukan untuk menjawab hipotesis sebagai berikut :

H0 : Tidak terdapat pengaruh antara ROE, PER, dan PTA terhadap perubahan laba di masa yang akan datang.

H1 : Terdapat pengaruh antara ROE, PER, dan PTA terhadap perubahan laba di masa yang akan datang

Tabel Hasil Uji Simultan (Uji F)

\begin{tabular}{ccccccc}
\hline \multirow{2}{*}{ Model } & $\begin{array}{c}\text { Sum of } \\
\text { Squares }\end{array}$ & df & $\begin{array}{c}\text { Mean } \\
\text { Square }\end{array}$ & F & Sig. \\
\hline \multirow{2}{*}{1} & Regression & 24,757 & 3 & 8,252 & 2,169 & \multirow{2}{*}{$454^{\mathrm{b}}$} \\
& Residual & 3,805 & 1 & 3,805 & & \\
& Total & 28,562 & 4 & & & \\
\hline
\end{tabular}

Sumber : Data Olahan Aplikasi SPSS 21.

Berdasarkan tabel 4.8 di atas dapat dilihat bahwa nilai $\mathrm{F}$ hitung diperoleh sebesar 2,169 dengan tingkat signifikansi 0,454 . Sedangkan pada tabel $\mathrm{F}$ dalam lampiran dengan signifikansi 0,05 diketahui df1 (jumlah variabel-1) atau 4-1=3 dan df2 (n-k-1) atau 5-3$1=1$, ( $\mathrm{n}$ adalah jumlah sampel dan $\mathrm{k}$ adalah jumlah variabel independen), diperoleh angka sebesar 216. Berdasarkan kriteria uji $\mathrm{F}$ yang telah ditentukan pada bab sebelumnya, oleh karena Fhitung $<$ Ftabel $(2,169<216)$ dan tingkat signifikansi $>0,05(0,454>0,05)$, maka keputusan yang diambil adalah $\mathrm{H}_{0}$ diterima dan $\mathrm{H}_{4}$ ditolak. Dengan kata lain bahwa persamaan regresi yang terbentuk dari variabel return on equity (X1), price earning ratio (X2), dan perputaran total aktiva (X3) sebagai variabel independen secara bersama-sama tidak berpengaruh terhadap perubahan laba di masa yang akan datang (Y) sebagai variabel dependen.

Uji Koefisien Determinasi
Tabel Hasil Uji Koefisien Determinasi
\begin{tabular}{ccccc}
\hline Model & R & R Square & $\begin{array}{c}\text { Adjusted R } \\
\text { Square }\end{array}$ & $\begin{array}{c}\text { Std. Error of } \\
\text { the Estimate }\end{array}$ \\
\hline 1 &, $931^{\text {a }}$ &, 867 &, 467 & 1,95070 \\
\hline \multicolumn{6}{c}{ Sumber: Data Olahan Aplikasi SPSS 21. }
\end{tabular}

Berdasarkan tabel 4.9 menunjukkan bahwa besarnya nilai $\mathrm{R}$ adalah 0,31 yang berarti bahwa hubungan ROE, PER, PTA dengan perubahan laba di masa yang akan datang adalah sebesar 93,10\% sedangkan untuk nilai adjusted $\mathrm{R}$ squarea adalah sebesar 0,867 yang berarti $86,70 \%$ variabel dependen perubahan laba di masa yang akan datang dipengaruhi oleh variabel independen yang meliputi ROE, PER, dan PTA. Sedangkan sisanya 13,30\% dijelaskan oleh variabel lain yang tidak terdapat dalam penelitian ini.

\section{KESIMPULAN DAN SARAN}

\section{Kesimpulan}

Berdasarkan hasil penelitian dan pembahasan pada bab sebelumnya maka penulis dapat menarik kesimpulan sebagai berikut:

1. Variabel X1 (Return On Equity) tidak berpengaruh dalam memprediksi perubahan laba di masa yang akan datang; 
2. Variabel X2 (Price Earning Ratio) tidak berpengaruh dalam memprediksi perubahan laba di masa yang akan datang;

3. Variabel X3 (Perputaran Total Aktiva) tidak berpengaruh dalam memprediksi perubahan laba di masa yang akan datang;

4. Variabel ROE, PER dan PTA secara simultan tidak berpengaruh dalam memprediksi perubahan laba di masa yang akan datang.

\section{Saran}

Bagi PT. Bank Rakyat Indonesia (Persero) Tbk, agar dapat memperhatikan memperhatikan faktor-faktor yang dapat memprediksi perubahan laba di masa yang akan datang. Diharapkan pihak bank dapat menarik nasabah ataupun investor agar dapat mengalami peningkatan laba. Bagi peneliti selanjutnya diharapkann agar dapat menggali variabelvariabel independen lainnya atau memperpanjang periode pengamatan untuk memprediksi perubahan laba di masa yang akan datang.

\section{DAFTAR PUSTAKA}

Abdel Rahman, 2013 “The Role Of Financial Analysis Ratio in Evaluating Performance. Interdiscplinary Journal of Contemporary Research in Busines.

Alizia Yocelyn, 2012, Analisis Pengaruh Perubahan Arus Kas dan Laba Akuntansi Terhadap Return Saham pada Perusahaan berkapitalisasi besar.

Assa R. M, 2010, Analisis Laporan Keuangan Dalam Memprediksi Perubahan Laba Di Masa Yang akan Datang Pada PT. Bank Negara Indonesia (Persero) Tbk.

Deny Liana Sutisno 2014, Analaisis Rasio Keuangan Dalam Memprediksi Kondisi Financial Distress Perubahan Manfaktur.

Fatimah S, 2012,Analisis Pengaruh Rasio Keuangan Terhadap Perubahan Laba Pada Perusahaan Manukfatur Sektor Aneka Industri Yang Terdaftar Di Bursa Efek Indonesia. Universitas Maritim Raja Ali Haji, Tanjungpinang.

Fadhillah R. Nasution 2011 Pengaruh Biaya Operasional Terhadap Laba Bersih Pada Bank Swasta Nasional Yang Terdaftar di Bursa Efek Indonesia Periode 2009-2011

Henry, 2015 Analisis Laporan Keuangan Penerbit Center for Academic Publishing Service Ida Nuryana 2013 Pengaruh Rasio Keuangan Terhadap Return Saham Perusahaan LQ 45 di Bursa Efek Jakarta.

Rahmawati 2013 "Pengaruh Good Corporate Govermance (GCG) Terhadap Manajemen Laba Pada Perusahaan Perbankan". Accounting Analysis Journal.

Sofyan Syafri Harahap 2012, Teori Akuntansi. Penerbit Erlangga Jakarta.

Shiifa Shareenda 2015, Analisis Laporan Keuangan Sebagai Dasar Untuk Menilai Kinerja Keuangan Pada PT.BPR Sidang Binaharta Lubuklinggau.

Situmorang P. A., 2014. Analisis Pengaruh Gross Profit Margin, Net Profit Margin, Earning Power Of Total Invesment dan Return On Equity Terhadap Perubahan Laba Pada Perusahaan Pertambangan Yang Terdaftar Di Bursa Efek Indonesia. Universitas Sumatera Utara, Medan.

Sumantri dan Teddy Jurnali 2010 Manfaat Rasio Keuangan Dalam Mempredisksi Kepalitan Bank Nasional.

Mabue Kumbirai and Robert Webb 2010 “ A Financial Ratio Analysis of Commercial Bank Performance in South Africa.

Paramawardhani N, 2015. Rasio Keuangan Dan Perubahan Laba Perusahaan Agroindustri Di Bursa Efek Indonesia. Universitas Jember, Jember.

//www.google.co.id/

//www.idx.co.id/

//www.BRI.co.id/ 